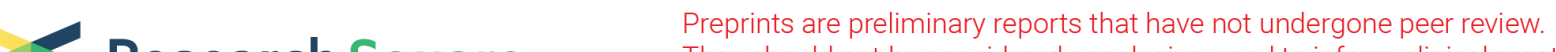 $\begin{array}{ll}\text { Research Square } & \text { They should not be considered conclusive, used to inform clinical practice, } \\ \text { or referenced by the media as validated information. }\end{array}$
}

\section{Association of Neural Tube Defects with maternal and neonatal serum vitamin B12 level in Bangladesh: A multicenter case control study}

\section{Fakhrul Amin}

Sheikh Hasina Medical College, Tangail

Abu Faisal Mohammad Pervez

Bangabandhu Sheikh Mujib Medical College and Hospital, Faridpur

Mohammod Shahidullah

BSMMU: Bangabandhu Sheikh Mujib Medical University

Abdul Mannan

BSMMU: Bangabandhu Sheikh Mujib Medical University

\section{Sanjoy Kumar Dey}

BSMMU: Bangabandhu Sheikh Mujib Medical University

Mohammad Kamrul Hasan Sabuj

BSMMU: Bangabandhu Sheikh Mujib Medical University

Ferdous Jahan Binte Rashid

Institute of Child and Mother Health

Hasnat Sujon ( $\nabla$ hasnatsujon@gmail.com )

Directorate General of Health Services, Ministry of Health and Family Welfare, Mohakhali, Dhaka https://orcid.org/0000-0001-6365-1298

Mohammad Habibur Rahman Sarker

Hiroshima University: Hiroshima Daigaku

\section{Research Article}

Keywords: Bangladesh, Neural Tube Defects, Newborn, Tertiary Care Centers, Vitamin B 12

Posted Date: February 2nd, 2022

DOI: https://doi.org/10.21203/rs.3.rs-1057032/v1

License: (c) (1) This work is licensed under a Creative Commons Attribution 4.0 International License. Read Full License 


\section{Abstract}

Background: Neural tube defects (NTDs), a congenital deformity of the central nervous system attributed to multifactorial etiology including nutritional factors e.g., folic acid deficiency. Some studies suggested deficiency of vitamin $B_{12}$ may be another factor behind NTDs due to its intimate metabolic pathway with folic acid. This study aimed to identify the association of NTDs with maternal and neonatal serum vitamin $\mathrm{B}_{12}$ level.

Methods: This case-control study was conducted from January 2014 to June 2015 in three tertiary level hospitals at Dhaka, Bangladesh. 32 cases (neonate with NTDs-mother pair) were selected from Bangabandhu Sheikh Mujib Medical University (BSMMU) Hospital (18), Dhaka Medical College Hospital (8) and Sir Salimullah Medical College and Mitford hospital (6). 40 age and sex matched controls were selected from BSMMU. A baseline assessment of the mothers on age, parity, education, residence, antenatal checkup, method of delivery and socio-economic status was taken. Vitamin $\mathrm{B}_{12}$ was estimated from the venous blood sample of the mother and newborn within 7 days after delivery. We considered $<200 \mathrm{pg} / \mathrm{ml}$ of vitamin $B_{12}$ as 'deficiency', $200-300 \mathrm{pg} / \mathrm{ml}$ as 'marginal deficiency' and $>300 \mathrm{pg} / \mathrm{ml}$ as 'normal'. Quantitative data were expressed as mean \pm SD and qualitative data were expressed as proportion. Chi-square test and student's unpaired t-test was used for comparison of categorical and continuous variables respectively. Pearson correlation was used to determine the correlation between continuous variables.

Result: Mothers with low socio-economic status $(p=0.004)$ and irregular antenatal checkup $(p=0.029)$ were significantly higher among the cases. Serum vitamin B12 level of mother $(p<0.01)$ and newborn $(p<0.01)$ were significantly lower among the cases. Vitamin B12 deficient newborn were significantly higher among the cases ( $50 \%$ vs. $25 \%$ ). Maternal and neonatal serum vitamin B12 levels were positively correlated with both case (Pearson $\mathrm{R}=0.517$ ) and control (Pearson $\mathrm{R}=0.627$ ) groups.

Conclusion: This study finding suggests that both maternal and neonatal low serum vitamin $\mathrm{B}_{12}$ level is associated with NTDs. Vitamin $B_{12}$ supplementation along with folic acid may be considered for to-bemothers to prevent NTDs.

\section{Background}

Being one of the common birth defects worldwide (Greene and Copp 2014), 0.3 million babies are born with neural tube defects (NTDs) worldwide every year, resulting in approximately 0.088 million deaths and 8.6 million disability-adjusted life years (Zaganjor et al. 2016). NTDs ranging from anencephaly causing death of the fetus to spina bifida occulta causing partial paralysis of the neonate develop during the first month of pregnancy due to non- or incomplete closure of neural tube (Wang et al. 2019). The etiology of NTDs is the additive involvement of several risk factors including genetic, environmental, and nutritional factors (Greene and Copp 2014). From a preventive point of view, maternal nutritional risk factors provide a battling front. 
Maternal folate deficiency has been widely regarded as an important risk factor to increase the vulnerability to NTDs in the fetus and up to $75 \%$ NTDs incidence has been reduced by folic acid supplementation to to-be-mothers (Zhang et al. 2009; Greene and Copp 2014; Kancherla et al. 2017). Several studies suggested that deficiency of other nutrients may have potential role in development of NTDs. Due to its close link to folate metabolism and as infant store and cord blood concentration of vitamin $B_{12}$ is linked to maternal serum vitamin $B_{12}$ level pre-pregnant and pregnant state, vitamin $B_{12}$ is perceived to be an important determinant of NTDs (Molloy et al. 2008; Molloy et al. 2009; Peker et al. 2016; Finkelstein et al. 2019).

One study reported that $42 \%$ of the pregnant mothers in Bangladesh are vitamin $B_{12}$ deficient (Riaz et al. 2018). Regarding NTDs, although a nationwide population-based data is unavailable, using available surveillance data, the reported prevalence in Bangladesh is 4.7 per 1000 live birth (Christianson et al. 2006). Despite the high prevalence of vitamin $B_{12}$ deficient mothers and almost twice of the global average prevalence of NTDs, no data is available in Bangladesh to distinguish the relationship of NTDs with maternal and newborn serum vitamin $\mathrm{B}_{12}$ level. Therefore, this hospital based multi-center study was aimed to identify the association of NTDs with maternal and neonatal serum vitamin $B_{12}$ level.

\section{Methods}

Study site and population: This case-control study was conducted from January 2014 to June 2015 in three tertiary level hospitals at Dhaka, Bangladesh: Bangabandhu Sheikh Mujib Medical University (BSMMU) Hospital, Dhaka Medical College Hospital (DMCH) and Sir Salimullah Medical College and Mitford Hospital (SSMCH). 32 cases (mother- neonate with NTDs pairs) were selected from the neonatal intensive care unit of BSMMU (18), DMCH (8) and SSMCH (6). 40 postnatal age and sex matched controls with diagnosis other than NTDs were selected from BSMMU. Mothers who took vitamin $\mathrm{B}_{12}$ or BComplex supplementation during pregnancy period, had history of diabetes mellitus, took anticonvulsant or antifolate drugs and/or had radiation exposure during the first trimester of pregnancy were excluded from the study (Figure 1).

\section{Laboratory method}

We draw 2-3 $\mathrm{ml}$ of venous blood for vitamin $\mathrm{B}_{12}$ estimation from the mother and newborn by venipuncture within 7 days after delivery and collected them in a capped polypropylene tube labeled with allocated number to reduce bias and transferred them to the department of biochemistry, BSMMU with standard procedure. Serum was separated by centrifugation (4000 rpm for 5 minutes), and hemolyzed sample was discarded. Serum vitamin B12 level was calculated using the Chemiluminescent Microparticle Immunoassay on Architect 2000 analyzer. We considered $<200 \mathrm{pg} / \mathrm{ml}$ of vitamin $\mathrm{B}_{12}$ as 'deficiency', 200-300 pg/ml as 'marginal deficiency' and >300 pg/ml as 'normal' (Yetim et al. 2019).

\section{Statistical analysis}


We analyzed the data using the SPSS version 20.0 of SPSS Inc., Chicago, IL. Quantitative data was expressed as mean \pm SD and qualitative data was expressed as proportion. We used Chi-square test and student's unpaired t-test for comparison of categorical and continuous variables respectively. Pearson correlation was used to determine the correlation between continuous variables. $p$ value of $<0.05$ was considered statistically significant.

\section{Results}

Among different types of NTDs observed among the study subjects, meningomyelocele (63\%) was the most common followed by encephalocele (15\%) and meningocele (9\%) (Figure 2).

Comparison on baseline characteristics of the mothers showed that lower socio-economic status and irregular antenatal checkup were significantly high among the case compared to the control. However, we observed no significant difference among age of mother, maternal parity, delivery of neonate by normal delivery, high socio-economic status, education and rural residence between case and control (Table 1).

Table 1

Baseline characteristics of mother between case and control group

\begin{tabular}{|c|c|c|c|}
\hline Baseline characteristics if mothers & Case $(n=32)$ & Control $(n=40)$ & $p$ value \\
\hline Age of mother in years (mean $\pm S D$ ) & $26.08 \pm 5.66$ & $25.73 \pm 4.36$ & 0.086 \\
\hline Parity of mother (mean \pm SD) & $1.87 \pm 1.8$ & $1.77 \pm 0.88$ & 0.127 \\
\hline Normal vaginal delivery of the neonate & $13(41)$ & $7(18)$ & 0.055 \\
\hline \multicolumn{4}{|l|}{ Socio-economic status ${ }^{a}$} \\
\hline Low & $12(38)$ & $3(8)$ & 0.004 \\
\hline Middle & $13(41)$ & $20(50)$ & 1 \\
\hline High & $7(21)$ & $17(42)$ & 0.111 \\
\hline \multicolumn{4}{|l|}{ Education } \\
\hline Illiterate & $5(16)$ & 0 & 1 \\
\hline$\geq 10$ years & $11(34)$ & $10(25)$ & 0.542 \\
\hline$<10$ years & $16(50)$ & $30(75)$ & 0.051 \\
\hline Rural residence & $15(47)$ & $21(53)$ & 0.812 \\
\hline Irregular antenatal checkup & $15(47)$ & $8(20)$ & 0.029 \\
\hline
\end{tabular}


We found that serum vitamin $B_{12}$ level of the mother and the newborn were significantly lower among the cases than the controls. No significant difference was observed between maternal deficiency and marginal deficiency of vitamin $\mathrm{B}_{12}$ between cases and controls. Vitamin $\mathrm{B}_{12}$ deficiency of newborn were significantly high among the cases than the controls; however, there was no significant association with marginal deficiency of vitamin $B_{12}$ between newborn of two groups (Table 2).

Table 2

Serum vitamin $B_{12}$ level of the mother and newborn between case and control groups.

\begin{tabular}{|c|c|c|c|}
\hline Characteristics & Case $(n=32)$ & Control $(n=40)$ & $\begin{array}{l}p \\
\text { value }\end{array}$ \\
\hline Serum vitamin $B 12(\mathrm{pg} / \mathrm{ml})$ of mother $($ mean $\pm \mathrm{SD})$ & $202.06 \pm 51.68$ & $276.25 \pm 89.02$ & $<0.01$ \\
\hline Serum vitamin B12 $(\mathrm{pg} / \mathrm{ml})$ of newborn (mean $\pm \mathrm{SD})$ & $238.09 \pm 64.37$ & $373.22 \pm 145.43$ & $<0.01$ \\
\hline \multicolumn{4}{|l|}{$\begin{array}{l}\text { Differential level of serum vitamin B12 }(\mathrm{pg} / \mathrm{ml}) \text { of } \\
\text { mother, } \mathrm{n}(\%)\end{array}$} \\
\hline Normal $(>300$ pg/ml) & $3(9)$ & $18(45)$ & 1 \\
\hline Marginal deficiency $(200-300$ pg/ml) & $13(41)$ & $12(30)$ & 0.48 \\
\hline Deficiency $(<200$ pg/ml) & $16(50)$ & $10(25)$ & 0.05 \\
\hline \multicolumn{4}{|l|}{$\begin{array}{l}\text { Differential level of serum vitamin B12 }(\mathrm{pg} / \mathrm{ml}) \text { of } \\
\text { newborn, } \mathrm{n}(\%)\end{array}$} \\
\hline Normal (>300 pg/ml) & $4(12)$ & $23(58)$ & 1 \\
\hline Marginal deficiency $(200-300$ pg/ml) & $20(63)$ & $15(37)$ & 0.06 \\
\hline Deficiency $(<200$ pg/ml) & $8(25)$ & $2(5)$ & 0.03 \\
\hline
\end{tabular}

In both case and control group, we observed statistically significant positive correlation between maternal and neonatal serum vitamin $\mathrm{B}_{12}$ levels (Figure 3 ).

\section{Discussion}

We have observed that the mean maternal serum $B_{12}$ level of the case mothers is lower than the control mothers. Moreover, $50 \%$ of the case mothers are vitamin $B_{12}$ deficient, which is only $25 \%$ in case of control mothers. Maternal vitamin $\mathrm{B}_{12}$ deficiency has been widely reported in low- and middle-income countries as well as in Bangladesh (Darnton-Hill and Mkparu 2015; Riaz et al. 2018; Darnton-Hill 2019). It is well documented that the deficiency of folate is an important risk factor for NTDs, although the mechanism by which folate causes NTDs is unknown (Greene and Copp 2014). The intimate linkage of vitamin $B_{12}$ with folate is due its cofactor activity for the enzyme methionine synthase, which uses 5methyltetrahydrofolate as a carbon donor. Thereby, deficiency of vitamin $\mathrm{B}_{12}$ can disrupt the intracellular folate pathway (Froese et al. 2019). Due to this closely linked metabolism, it has been discussed that 
cellular uptake and utilization of folate cofactors can be augmented by vitamin $\mathrm{B}_{12}$ supplementation, which in turn can prevent NTDs. Moreover, it has also been argued that food fortification with combined folic acid and vitamin $B_{12}$ may yield prevent NTDs better than folic acid alone as vitamin $B_{12}$ might have a self-determining role in this case (Molloy 2018).

Fetal and newborn vitamin $\mathrm{B}_{12}$ status is thought to be determined by the maternal vitamin $\mathrm{B}_{12}$ status during pregnancy (Finkelstein et al. 2019). Vitamin $B_{12}$, facilitated by transcobalamin, is transported across the placenta, although very little is known about this pathway from the maternal to the fetal circulation. Further, the placenta can regulate fetal $\mathrm{B}_{12}$ uptake and reduced transcobalamin synthesis which causes vitamin $B_{12}$ deficiency to the neonate (Finkelstein et al. 2015). We have found that NTDs affected newborns had a lower level of serum vitamin $B_{12}$ level compared to the unaffected newborns and affected newborns have a higher percentage of either deficiency or marginal deficiency of vitamin $B_{12}$. A positive correlation was also revealed between the mother and newborn of both groups, that is the lower the mother's serum vitamin $B_{12}$, the lower was the baby's serum vitamin $B_{12}$ and vice versa which has been documented elsewhere (Molloy et al. 2009). This also emphasize the discussion of vitamin $B_{12}$ supplementation to the to-be-mothers.

In our study, NTDs mother are mostly from low socioeconomic status. Possible explanations of low level in these populations were due to low animal source food intake, religious believe, malabsorption in developing countries for their poor socio-economic condition (Villamor et al. 2008; Obeid et al. 2019). We also observed $\mathrm{d}$ a higher rate of history of irregular antenatal check-up among the case mothers which might be due to their financial burden. Worldwide meningomyelocele and encephalocele are the two most common birth defect among the NTDs (Laharwal et al. 2016; Sarmast et al. 2016) which is also our findings.

\section{Strength and limitations}

Strength of this study its being case-control in nature. We have taken at least one age and sex matched control in this multicenter study. However, sample of the study was small and causes of NTDs were not considered in the study.

\section{Conclusion}

This study finding suggests that both maternal and neonatal low serum vitamin $\mathrm{B}_{12}$ level is associated with NTDs. Further study with large sample size would yield a more acceptable finding in this regard. Vitamin $\mathrm{B}_{12}$ supplementation along with folic acid should be considered for to be mothers to prevent NTDs. Large multicenter randomized control trial may be carried out to establish whether periconceptional vitamin $\mathrm{B}_{12}$ supplementation decreases NTDs.

\section{Abbreviations}


Neural Tube Defects, NTDs; Bangabandhu Sheikh Mujib Medical University, BSMMU; Dhaka Medical College Hospital, DMCH; Sir Salimullah Medical College and Mitford Hospital, SSMCH

\section{Declarations}

Ethics approval and consent to participate: Ethical approval was taken from institutional review board of BSMMU. Written informed consent was taken from the mother.

Consent for publication: Not applicable

Availability of data and material: The datasets used and/or analyzed during the current study are available from the corresponding author on reasonable request.

Competing interests: The authors declare that they have no competing interests.

Funding: This self-funded research study was Fakhrul Amin's (first author) Doctor of Medicine (MD) thesis.

Authors' contributions: FA, AFMP, MS coined the idea and designed the study; FA. AM, SKD, MKHS, FJBR collected the data; FA, HS and MHRS analyzed and interpret the data; FA, HS and MHRS wrote the first draft of the manuscript; all authors reviewed, revised, and approved the final version of the manuscript to be published.

Acknowledgements: We are grateful to all the study participants and authorities of BSMMU, DMCH and SSMCH. We are also thankful to our MD Phase A and Phase B students, and Departments of neonatology of BSMMU for their generous support.

\section{References}

1. Christianson A, Howson CP, Modell B (2006) March of Dimes global report on birth defects: the hidden toll of dying and disabled children. White Plains, NY

2. Darnton-Hill I (2019) Public Health Aspects in the Prevention and Control of Vitamin Deficiencies. Current Developments in Nutrition 3. https://doi.org/10.1093/cdn/nzz075

3. Darnton-Hill I, Mkparu UC (2015) Micronutrients in pregnancy in low- and middle-income countries. Nutrients 7:1744-1768. https://doi.org/10.3390/nu7031744

4. Finkelstein JL, Guillet R, Pressman EK, Fothergill A, Guetterman HM, Kent TR, O'brien KO (2019) Vitamin B 12 status in pregnant adolescents and their infants. Nutrients 11. https://doi.org/10.3390/nu11020397

5. Finkelstein JL, Layden AJ, Stover PJ (2015) Vitamin B-12 and Perinatal Health. Advances in Nutrition 6:552-563. https://doi.org/10.3945/an.115.008201 
6. Froese DS, Fowler B, Baumgartner MR (2019) Vitamin B12, folate, and the methionine remethylation cycle-biochemistry, pathways, and regulation. J Inherit Metab Dis 42:673-685. https://doi.org/10.1002/jimd.12009

7. Greene NDE, Copp AJ (2014) Neural tube defects. Annu Rev Neurosci 37:221-242

8. Kancherla V, Ibne Hasan MOS, Hamid R, Paul L, Selhub J, Oakley G, Quamruzzaman Q, Mazumdar M (2017) Prenatal folic acid use associated with decreased risk of myelomeningocele: A case-control study offers further support for folic acid fortification in Bangladesh. PLoS ONE 12:e0188726. https://doi.org/10.1371/journal.pone.0188726

9. Laharwal M, Sarmast A, Ramzan A, Wani A, Malik N, Arif S, Rizvi M (2016) Epidemiology of the neural tube defects in Kashmir Valley. Journal of Pediatric Neurosciences 11:213-218. https://doi.org/10.4103/1817-1745.193368

10. Molloy AM (2018) Should vitamin B12 status be considered in assessing risk of neural tube defects? Ann N Y Acad Sci 1414:109-125. https://doi.org/10.1111/nyas.13574

11. Molloy AM, Kirke PN, Brody LC, Scott JM, Mills JL (2008) Effects of folate and vitamin B12 deficiencies during pregnancy on fetal, infant, and child development. FoodNutr Bull 29. https://doi.org/10.1177/15648265080292s114

12. Molloy AM, Kirke PN, Troendle JF, Burke H, Sutton M, Brody LC, Scott JM, Mills JL (2009) Maternal vitamin B12 status and risk of neural tube defects in a population with high neural tube defect prevalence and no folic acid fortification. Pediatrics 123:917-923. https://doi.org/10.1542/peds.2008-1173

13. Obeid R, Heil SG, Verhoeven MMA, van den Heuvel EGHM, de Groot LCPGM, Eussen SJPM (2019) Vitamin B12 intake from animal foods, biomarkers, and health aspects. Frontiers in Nutrition 6. https://doi.org/10.3389/fnut.2019.00093

14. Peker E, Demir N, Tuncer O, Üstyol L, Balahoroğlu R, Kaba S, Karaman K (2016) The levels of vitamın B12, folate and homocysteine in mothers and their babies with neural tube defects. Journal of Maternal-Fetal and Neonatal Medicine 29:2944-2948. https://doi.org/10.3109/14767058.2015.1109620

15. Riaz M, Shaikh F, Fawwad A, Hakeem R, Shera AS, Hitman GA, Bhowmik B, Vale Moreira NC, Basit A, Hussain A (2018) Maternal Nutrition during Early Pregnancy and Cardiometabolic Status of Neonates at Birth. Journal of diabetes research 2018:7382946. https://doi.org/10.1155/2018/7382946

16. Sarmast AH, Laharwal MA, Ramzan AU, Wani AA, Malik NK (2016) A single center study of epidemiology of neural tube defects. Journal of Neurosciences in Rural Practice 7:462-465. https://doi.org/10.4103/0976-3147.182771

17. Villamor E, Mora-Plazas M, Forero Y, Lopez-Arana S, Baylin A (2008) Vitamin B-12 status is associated with socioeconomic level and adherence to an animal food dietary pattern in Colombian school children. J Nutr 138:1391-1398. https://doi.org/10.1093/jn/138.7.1391 
18. Wang M, de Marco P, Capra V, Kibar Z (2019) Update on the Role of the Non-Canonical Wnt/Planar Cell Polarity Pathway in Neural Tube Defects. https://doi.org/10.3390/cells8101198. Cells 8

19. Yetim A, Aygün E, Yetim Ç, Ucar A, Karakaş Z, Gökçay G, Demirkol M, Ömer B, Gökçay G, Baş F, Erginöz E, Dağoğlu T (2019) Measurement of serum vitamin B12-related metabolites in newborns: implications for new cutoff values to detect B12 deficiency. Journal of Maternal-Fetal and Neonatal Medicine 34. https://doi.org/10.1080/14767058.2019.1633301

20. Zaganjor I, Sekkarie A, Tsang BL, Williams J, Razzaghi H, Mulinare J, Sniezek JE, Cannon MJ, Rosenthal J (2016) Describing the prevalence of neural tube defects worldwide: A systematic literature review. PLoS ONE 11. https://doi.org/10.1371/journal.pone.0151586

21. Zhang T, Xin R, Gu X, Wang F, Pei L, Lin L, Chen G, Wu J, Zheng X (2009) Maternal serum vitamin $B 12$, folate and homocysteine and the risk of neural tube defects in the offspring in a high-risk area of China. Public Health Nutr 12:680-686. https://doi.org/10.1017/S1368980008002735

\section{Figures}




\section{6 enrolled mother- baby pairs}

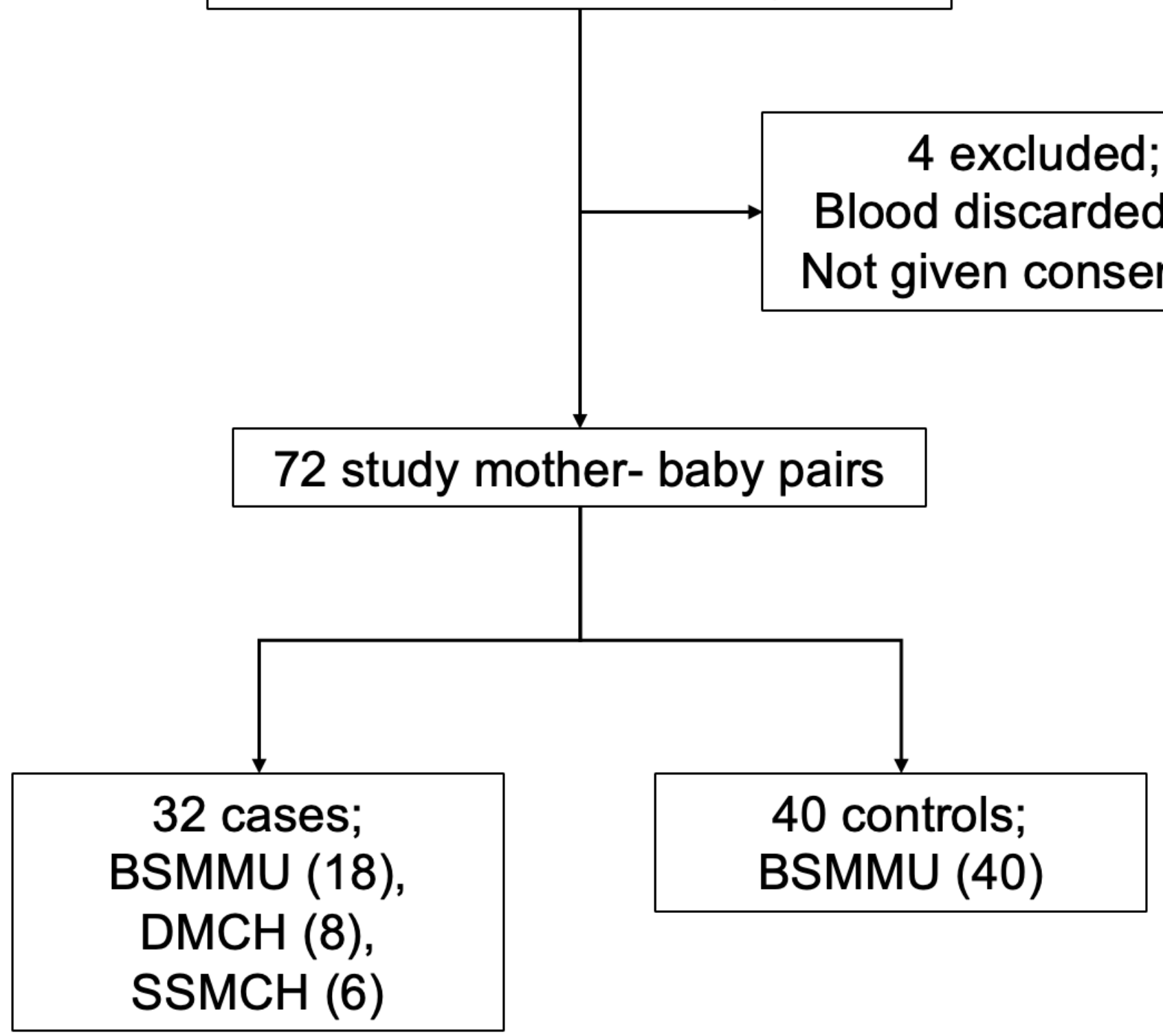

Figure 1

Study profile.

BSMMU= Bangabandhu Sheikh Mujib Medical University Hospital; DMCH= Dhaka Medical College Hospital; SSMCH= Sir Salimullah Medical College and Mitford Hospital 


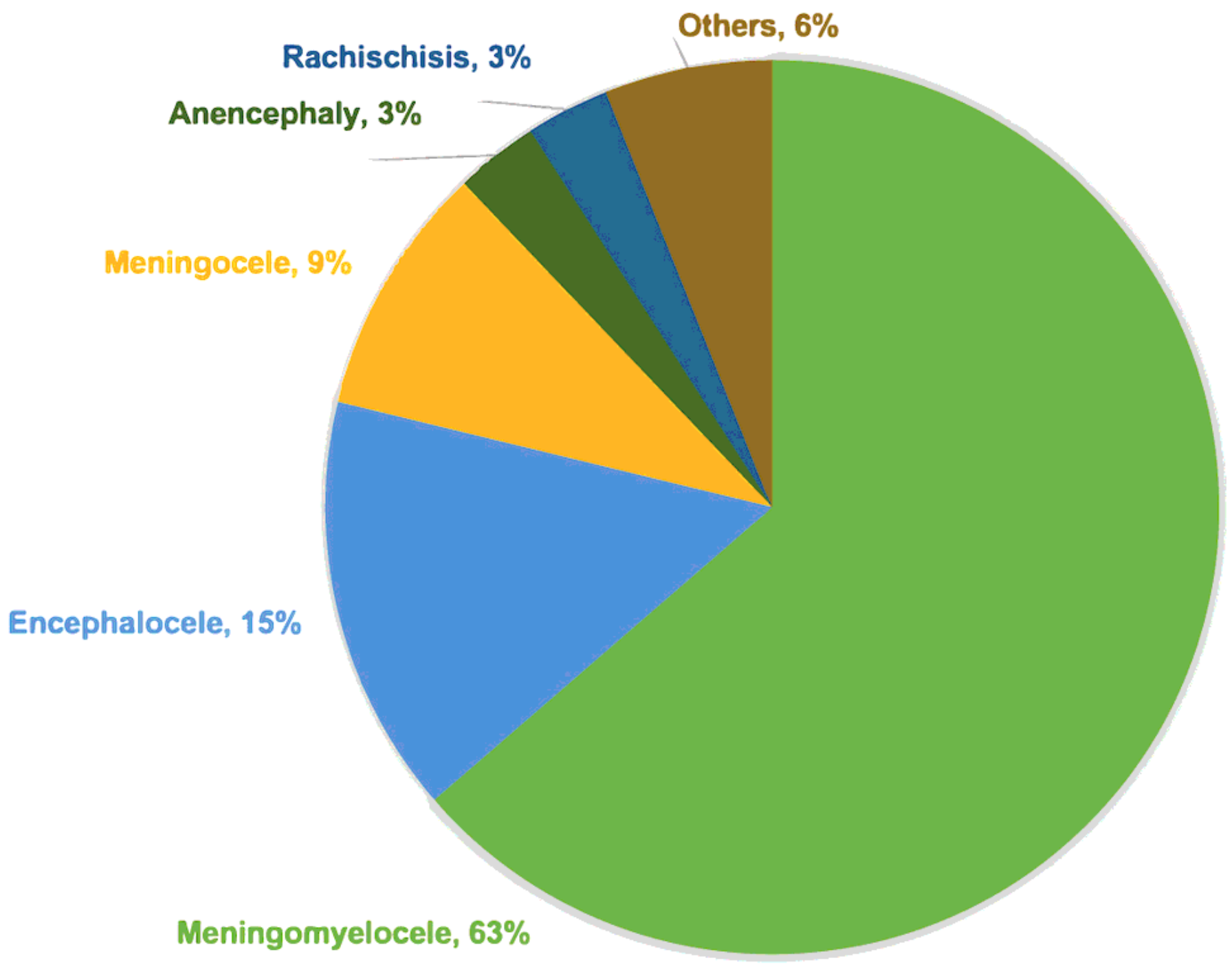

Figure 2

Different types of neural tube defects observed among cases $(n=32)$. 

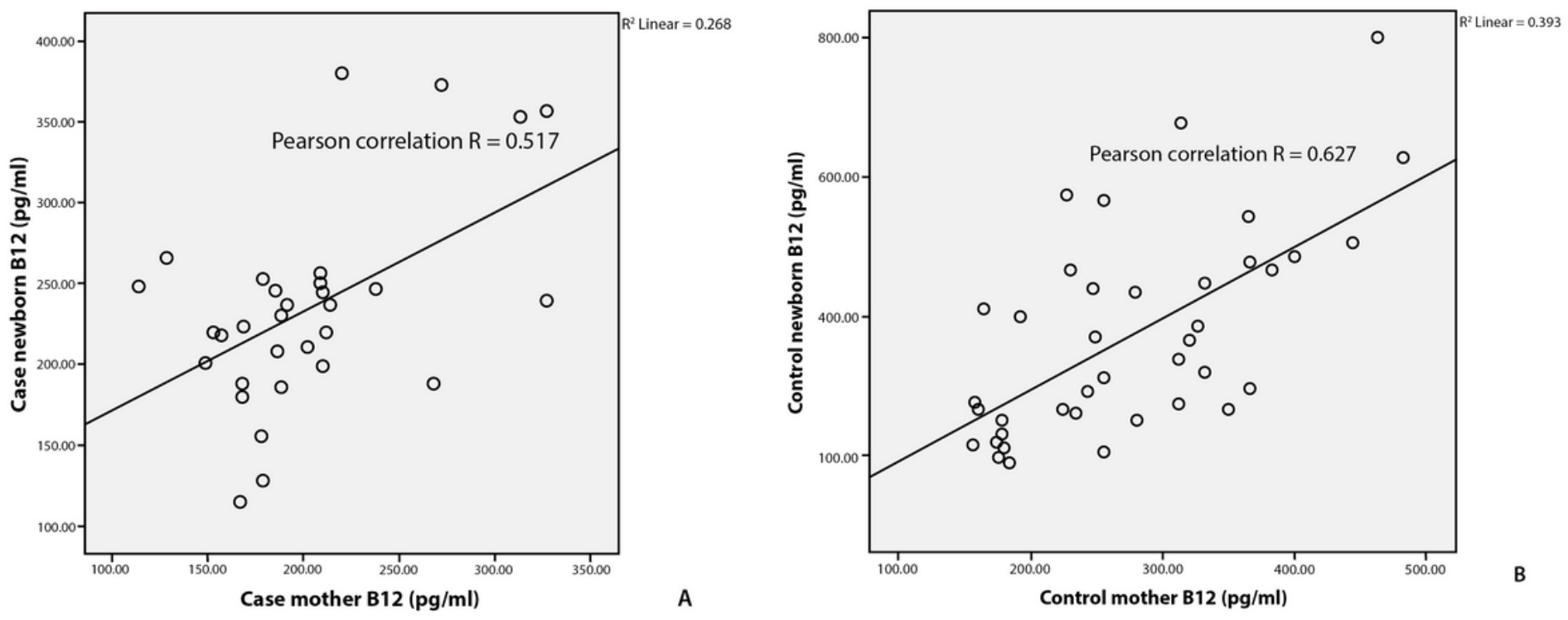

Figure 3

Correlation of serum vitamin B12 between mother and newborn.

A. Case; B. Control 